\title{
The Effect of Self-efficiency and the Environment of School on the Learning Achievement of Creative Products and Entrepreneurship Subjects at SMKN 1 Trowulan Mojokerto, East Java Indonesia
}

\author{
Heru Totok Tri Wahono*, J. G. Nirbito, Hari Wahyono, Sunaryanto \\ Department of Economics Education, Universitas Negeri Malang, Malang, 65145, Jawa Timur, Indonesia
}

Received September 28, 2020; Revised December 4, 2020; Accepted December 13, 2020

\begin{abstract}
Cite This Paper in the following Citation Styles
(a): [1] Heru Totok Tri Wahono, J. G. Nirbito, Hari Wahyono, Sunaryanto, "The Effect of Self-efficiency and the Environment of School on the Learning Achievement of Creative Products and Entrepreneurship Subjects at SMKN 1 Trowulan Mojokerto, East Java Indonesia," Universal Journal of Educational Research, Vol. 8, No. 12B, pp. 8508 - 8513, 2020. DOI: 10.13189/ujer.2020.082661.
\end{abstract}

(b): Heru Totok Tri Wahono, J. G. Nirbito, Hari Wahyono, Sunaryanto (2020). The Effect of Self-efficiency and the Environment of School on the Learning Achievement of Creative Products and Entrepreneurship Subjects at SMKN 1 Trowulan Mojokerto, East Java Indonesia. Universal Journal of Educational Research, 8(12B), 8508 - 8513. DOI: 10.13189/ujer.2020.082661.

Copyright $\bigcirc 2020$ by authors, all rights reserved. Authors agree that this article remains permanently open access under the terms of the Creative Commons Attribution License 4.0 International License

\begin{abstract}
Quality human resources will certainly have a big role in efforts to build the country. One of the ways to improve human resources is to improve quality education. Therefore, the purpose of this study was to discover: (1) the effect of self-efficacy on learning achievement of Creative Products and Entrepreneurship subjects at SMKN 1 Trowulan Mojokerto, East Java, Indonesia, (2) the effect of self-efficacy and school environment on learning achievement of Creative Products and Entrepreneurship at SMKN 1 Trowulan Mojokerto, East Java Indonesia, this study was a quantitative research with a correlational approach, which data collection techniques used documentation with a questionnaire instrument. The data analysis in this study used multiple linear regression techniques with the help of the SPSS 20 application. Multiple linear regression techniques included the $\mathrm{F}$ test and the $\mathrm{T}$ test. The results of this study indicated that it had a positive and significant relationship between self-efficacy and the school environment with student achievement in creative products and entrepreneurship at SMKN 1 Trowulan Mojokerto Indonesia, this was evidenced by the results of testing the significance of multiple linear regression which showed the value of sig. $<0.05$. If students have a high level of self-efficacy and the
\end{abstract}

state of the school environment, the learning achievement of Creative Products and Entrepreneurship students of SMKN 1 Trowulan is high, and vice versa. The contribution of the self-efficacy variable and the school environment on the learning achievement variable of Creative Products and Entrepreneurship for students of SMKN 1 Trowulan was $44.7 \%$.

Keywords Self-efficacy, School Environment, Learning Achievement

\section{Introduction}

The progress of a country can be seen from the indicators of the quality of its human resources. Quality human resources will certainly have a big role in efforts to build the country. This can happen due to these human resources will carry out all activities of the country. For example, economic activities, politics, law, and others. If the activities of a country can run efficiently with superior and quality human resources.

One of the ways to improve human resources is to 
improve quality education. If education in a country is not filtered or lacking in quality, it can lead to a decrease in human resources which causes the country to be underdeveloped and underdeveloped. Nowadays, the superiority of a country is not only measured by its natural resources but also by human resources. There have been many that can be used as examples of countries with few natural resources but having the quality of human resources so that these countries become developed countries, to make quality human resources, quality education can be seen from the achievement of student.

Schools as one of the formal educational institutions must be able to provide quality education. Schools are demanded to manage human resources which are expected to produce quality graduates who are guided by the needs of the society and it can contribute to national development. In an educational institution, the success of the teaching and learning process is achieved by students. According to Arifin (2011), learning achievement can be used as an indicator of the success of an educational institution in conducting the education.

Djamarah (2012) reveals that achievement as a result of an activity that has been carried out, is created, both individually and in groups. Corresponding with Djamarah, Poerwadarminta in Djamarah (2012) argues that achievement is the result that has been achieved (done, undertaken, and so on). Meanwhile, the meaning of learning achievement in the Big Indonesian Dictionary (2005) is the mastery, knowledge, or skills developed through which are usually determined by the test scores or the scores given by the teacher. On the other hand, Suryabrata (2002) points out that learning achievement is a value which is the final formulation given by the teacher regarding the progress or learning outcomes of their students during a certain period. Syah (2006) defines learning achievement as a learning outcome that includes all areas of psychology that change as a result of experiences and the teaching and learning process (in Janatin, 2015).

The achievement of student learning is the result that obtained after carrying out a series of learning processes, which is indicated quantitatively by the numerical value given by the teacher on the subject of creative products 4 and entrepreneurship. This implies that learning achievement is a reflection of the results that obtained during the learning process. Thus, the students do not necessarily just follow the learning process but students also take part in the learning process, in order to train confidence and confidence when there are problems in the learning process so that students become active in the class. There are two factors that influence learning achievement, namely internal factors and external factors. According to Slameto (2010), internal factors include physical, psychological and fatigue factors. Meanwhile, external factors include family, school and society As for Muhibin Syah, apart from these two factors, there is one other factor, namely the learning approach factor. Student learning success is measured by daily tests, midterm and final semester exams (in Sufirmansyah 2015).

Factors that come from within the students, cover two aspects, namely the physiological aspects and the psychological aspects. Physiological aspects are aspects that are physical. The conditions of students in receiving subjects and teachers are included in the physiological aspects. Meanwhile, the psychological aspects cover the aspects that are spiritual in nature. One of the factors that includes psychological aspects is self-efficacy of students (Syah 2011).

In daily life, it is self-efficacy that leads itself to determine the challenging goals and to survive all the difficulties that occur. People who have high self-efficacy mean that this person can be interpreted as having high confidence to achieve academic success with their abilities. It is different with the people who have low self-efficacy, before doing something, the person already thinks that he will fail and cannot achieve what is expected. Therefore, belief in ourself is very necessary to motivate to do everything that we want. 6 Self-efficacy also plays a role in the learning process and definitely it will always interact with the environment. The environment itself has provided stimulation to individuals and on the other hand, individuals respond to individuals. And conversely, individuals can also respond to the environment, starting from changes in behavior, both positive and negative behavior, which will occur because there is a process of interaction between individuals and the environment. According to Hamalik (2009), environment is everything in the natural environment that has a certain meaning or effect on individuals (in Amalia 2014).

The self-efficacy of students at SMK Negeri 1 Trowulan is very lacking. Most students lack of confidence in themselves. Even they answer questions that given by the teacher. When the teachers give a question to one of the students, the students who are asked the question, are still hesitant and afraid to answer due to the person feel worried if the answer will be wrong. Dealing with the phenomenon, the self-efficacy is emerged to make students to be more confident in themselves, both in how to answer questions and in everything that they do. In connection with the academic world, self-efficacy is interpreted as a personal assessment of one's ability to organize and carry out tasks to gain achievement. Zimmerman, 2009). Ottens (1991) explains that students who accept false beliefs about how to set values in themselves, how to motivate themselves, and how to deal with anxiety are wrong thinking that causes the anxiety to arise. Thus, self-efficacy is needed by students so that anxiety does not arise.

Widyoko (2009) states that according to the behavioristic flow, learning activities occur because of conditions or stimuli from the environment. Learning 
activities are a response or reaction to conditions or environmental stimuli. Whether someone learns or not depends on the conditional factors of the environment. The environment can be in the form of a family environment, society environment, or school environment. The school environment 7 consists of teachers, learning media, text books, curriculum, school friends, school regulations, and other learning resources (in Amalia 2014) The school environment is one of the factors that has a big influence on the development of children's behavior. In the school environment, definitely, there is a teacher's personal behavior, and the behavior of schoolmates and many more. In this case, definitely, students are taught to adapt to the environment around them. Environmental adaptation will certainly have an impact on students' self-efficacy which will build a spirit of belief that exists in these students. This impact will make students confident in their environment to interact with one another and will help students in the learning process to improve student achievement. The environment and student self-efficacy have an effect on learning achievement. The environment at SMK Negeri 1 Trowulan supports because the layout of the school is in the middle of a rice field where it is hot during the day and away from vehicle noise Besides, students can also be affected by an environment that is not supportive, mostly there are students who gather and sometimes what is discussed is not about lessons but other things. If students talk about a lesson, what is discussed is that there are things that are not understood about the lesson and the student is afraid to ask questions that have not been understood.

With the high efficacy in creative products and entrepreneurship subjects, it will encourage students to be diligent in paying attention and looking for learning strategies to build entrepreneurial traits in students. Students who have high efficacy, they will be easy to find creative ideas to develop an entrepreneurial spirit through learning achievement. Meanwhile, towards students who have low efficacy, the teacher also has a role to support and pay attention to both the learning process and the environment around them.

However, in reality today, many teachers and students do not realize the importance of the role of self-efficacy. Many teachers consider that learning achievement is merely influenced by intelligence and ignores student self-efficacy. Many teachers argue that students who have high intelligence, they will get good grades, and vice versa. Even though students who are clever, they do not always get satisfactory learning achievement. Thus, learning achievement is not only influenced by intelligence but self-efficacy and the school environment as well. Learning achievement can be interpreted as the results achieved during the learning process at school (Green, 2006). Duncan, Dowsett, Claessens, Magnuson, Huston, Klebanov, \& Japel (2007) suggest that learning achievement includes academic achievement which is a cumulative process that involves mastery of new skills and enhancing previously owned skills. Knollman and Wild (2007) also state that student achievement is largely determined by parental support, such as parental involvement and motivation in helping the learning process.

Regarding to the background above and the description above, the researcher was interested in conducting a study entitled "The Effect of Self-Efficacy and the School Environment on Learning Achievement in Creative Products and Entrepreneurship Subjects at SMKN 1 Trowulan Mojokerto, East Java Indonesia".

This study was aimed to find out: (1) the effect of self-efficacy on learning achievement in Creative Products and Entrepreneurship subjects at SMKN 1 Trowulan Mojokerto, East Java Indonesia, (2) the effect of self-efficacy and school environment on learning achievement in the Creative Products and Entrepreneurship subjects at SMKN 1 Trowulan Mojokerto, East Java, Indonesia.

\section{Materials and Methods}

This research was a quantitative research. According to Arikunto (2006), many quantitative research is required to use numbers, starting from data collection, interpretation of the data, and the appearance of the results. The reason for choosing this study was that the researcher wanted to know the effect between variables and description in statistics. While the type of research was correlational. Correlational research aims to determine the relationship of a variable with other variables. The relationship between variables is expressed by the magnitude of the correlation coefficient and statistical significance (Sukmadinata, 2011). Thus, in this study, the researcher intented to describe the relationship between the self-efficacy variable and the school environment that has already existed in students, with learning achievement without giving any treatment to students. The population in this study was all students of class XI SMKN 1 Trowulan with a sample that took from that population.

Collecting data is an effort required to obtain various data needed. To obtain complete data as needed in this study, the data collection techniques used were documentation. The research instrument is a tool for collecting data.

The instruments used in this study were a self-efficacy questionnaire and a school environment questionnaire. The self-efficacy questionnaire indicator in this study was adapted from Janatin's thesis (2015), while the school environment questionnaire indicator was adapted from Amalia's thesis (2014). The measurement design used a Likert scale with four alternative answer choices consisting of groups of favorable and unfavorable items starting from SS (Strongly Agree), S (Agree), TS 
(Disagree), STS (Strongly Disagree). Respondents can give a sign $(\sqrt{ })$ in the available column according to their situation. The preparation of questionnaires was based on indicators of self-efficacy and the school environment. Following are the details of the formulation of behavioral indicators of self-efficacy and the school environment.

Table 1. The formulation of variable indicator

\begin{tabular}{|c|c|}
\hline Variable & Indicator \\
\hline \multirow{3}{*}{ Self Efficacy } & The success of other people \\
\cline { 2 - 2 } & The success experience \\
\cline { 2 - 2 } & Verbal Persuasion \\
\cline { 2 - 2 } & Physiological Condition \\
\hline \multirow{2}{*}{ The School Environment } & The Teacher's Personality \\
\cline { 2 - 2 } & Peer friends \\
\hline
\end{tabular}

Table 2. Score of each questionnaire answer

\begin{tabular}{|c|c|c|}
\hline The Answer Choices & Favourable Score & Unfavourable Score \\
\hline $\begin{array}{c}\text { Extremely Agree } \\
\text { (ST) }\end{array}$ & 4 & 1 \\
\hline Agree (S) & 3 & 2 \\
\hline Disagree (TS) & 2 & 3 \\
\hline $\begin{array}{c}\text { Extremely Disagree } \\
\text { (STS) }\end{array}$ & 1 & 4 \\
\hline
\end{tabular}

A good instrument must meet two important requirements, namely validity and reliability. In order for the results of a study to be valid and reliable, the instruments used must be valid and reliable (Sugiyono, 2012). Therefore, the instrument that will be used, must be tested for its validity and reliability. The validity and reliability tests carried out in this study are as follows:

\section{Validity}

An instrument is mentioned to be valid if it can be used to measure what should be measured (Sugiyono, 2012). In this study, the process of testing the validity used construct validity. According to Sugiyono (2018), testing the validity of the construct can be undertaken with an expert opinion (expert judgment). In this regard, after the instrument has been compiled on the aspects to be measured based on a certain theory, then it will be consulted to the experts. After the test of the construct from the expert is complete, it is followed by testing the instrument. The instrument was tested first on 52 students of class XI at SMKN 1 Trowulan who were not included in the research sample. From the results of the trial, the validity of the items was tested by correlating the total score of the items with the total score obtained by the students. In this study, testing the validity of items used the application of statistical product and service solutions (SPSS) version 20.

\section{Reliability}

An instrument can be mentioned as reliable if it can be used to measure the same object several times, it will produce the same data (Sugiyono, 2018). Reliability testing for interval / essay data types can be carried out using the Cronbach Alpha technique.

In this study, to test the reliability of the instrument, the researcher also used the help of the SPSS version 20 application. After obtaining the reliability coefficient, then to decide whether the instrument is reliable or not, the price is compared with the value of the Product Moment $r$ table at a significance of 0.05 . and adjusted to the amount of data. If $r 11$ is smaller than $r$ table, then the item is not reliable.

Analysis of the data in this study used the multiple linear regression techniques with the help of the SPSS 20 application. Multiple linear regression techniques cover the $\mathrm{F}$ test and the $\mathrm{T}$ test. Before performing multiple linear regression, it is required to test the classical assumption first. The data analysis steps are: (1) Descriptive Analysis, after obtaining data regarding self-efficacy and learning achievement, the researcher needs to carry out a descriptive analysis by making a frequency distribution table to describe the frequency of each variable and categorizing the variables into high, medium, and low; (2) The classical assumption test consists of linearity test, normality test, heteroscedasticity test and multicollinearity test.

\section{Result and Discussion}

In this study, the data obtained from: 1) Self-efficacy questionnaires to find out the level of self-efficacy of students; 2) Environmental questionnaire to discover the environmental conditions of students in learning; and 3) the result of PTS score in the odd semester on Creative Products and Entrepreneurship subjects to know the student achievement.

\section{A. The Questionnaire Result of the Self Efficacy Variable (X1)}

Based on the results of the distribution of questionnaires regarding self-efficacy to 150 class XI students, it can be seen that the average score of each indicator of the Self Efficacy variable can be seen as follows:

Table 3. Average Score per Indicator of Self Efficacy Variable

\begin{tabular}{|c|c|c|c|}
\hline \multirow{2}{*}{ Variable } & Indicator & $\begin{array}{c}\text { The Average } \\
\text { Score Per } \\
\text { Indicator }\end{array}$ & Description \\
\hline \multirow{5}{*}{$\begin{array}{c}\text { Self } \\
\text { Efficacy }\end{array}$} & $\begin{array}{c}\text { The success } \\
\text { experience }\end{array}$ & 2,62 & Medium \\
\cline { 2 - 4 } & $\begin{array}{c}\text { The experience } \\
\text { of other people }\end{array}$ & 2,87 & Medium \\
\cline { 2 - 4 } & $\begin{array}{c}\text { Verbal } \\
\text { persuasion }\end{array}$ & 2,69 & Medium \\
\cline { 2 - 4 } & $\begin{array}{c}\text { Physiological } \\
\text { Condition }\end{array}$ & 3,04 & Medium \\
\hline
\end{tabular}


Based on the results of the table 3, it can be seen that the four indicators of the Self Efficacy variable indicate that the value of each indicator is moderate. The average success experience score is 2.62, other people's experience is 2.87 , verbal persuasion is 2.69 and the physiological condition is 3.04 . It can be concluded that the average value of the self-efficacy variable is 2.81 with a moderate category.

B. The Questionnaire Result of the School Environment Variable (X2)

Based on the results of distributing questionnaires about the school environment to 150 class XI students, it can be seen that the average score of each indicator of the school environment variable can be seen as follows:

Table 4. Average Scores per Indicator of School Environment

\begin{tabular}{|c|c|c|c|}
\hline Variable & Indicator & $\begin{array}{c}\text { The Average } \\
\text { Score Per } \\
\text { Indicator }\end{array}$ & Description \\
\hline \multirow{2}{*}{$\begin{array}{c}\text { School } \\
\text { Environment }\end{array}$} & $\begin{array}{c}\text { The teacher's } \\
\text { personality }\end{array}$ & 2,87 & Medium \\
\cline { 2 - 4 } & Peer friends & 2,77 & Medium \\
\hline
\end{tabular}

From the results of the table above, it can be seen that the two indicators of the school environment variable show that the value of each indicator is moderate. The average personal score of teachers is 2.87, peers are 2.77. It can be concluded that the average value of environmental variables is 2.82 in the category of moderate.

C. The Variable of Learning Achievement on Creative Products and Entrepreneurship (Y)

The data of student achievement on Creative Products and Entrepreneurship subjects were obtained from the PTS scores of students of SMKN 1 Trowulan in the 2018/2019 academic year. The results of the descriptive analysis show that the average score is $84.03,62$ students who gain score above the average are 53 students and those who gain a score below the average are 97 students.

\section{Conclusions}

1. There was an effect of self-efficacy on the learning achievement of Creative Products and Entrepreneurship for students of SMKN 1 Trowulan in the 2018/2019 academic year. Based on the influence, the higher of the student's self-efficacy, the higher the self-efficacy on learning achievement. Conversely, if the self-efficacy of students is very low, then the self-efficacy of students will decrease.

2. There was no significant effect of the school environment on the learning achievement of Creative Products and Entrepreneurship for students at SMKN 1 Trowulan in the 2018/2019 academic year. Based on there is no significant influence, the school environment around the students does not affect student achievement.

3. There is an effect of self-efficacy and the school environment on learning achievement of Creative and Entrepreneurship Products at SMKN 1 Trowulan in the 2018/2019 academic year. If students have a high level of self-efficacy and the state of the school environment, the learning achievement of 75-76 Creative and Entrepreneurship Products of the students at SMKN 1 Trowulan is high, and vice versa.

\section{Acknowledgements}

We are very grateful to teachers of Vocational Senior High School for their attempts in teaching and learning of many talents and skills for upgrade the students. Hopefully what we found by this research can be the great material to change the students' paradigm that is used by all the Vocational Education teachers.

\section{REFERENCES}

[1] Arifin, Zainal. (2011). Learning Evaluation. Bandung, Indonesia: PT Remaja Rosdakarya.

[2] Arikunto, Suharsimi. Research Procedure: Practical Approach. Jakarta, Indonesia: Rineka Cipta.

[3] Bandura, A. (1997). Self Efficacy: The Exercise of Control. New York, NY: W.H. Freeman and Company.

[4] Duncan, G.J., Dowsett, C.J., Claessens, A., Magnuson, K., Huston, A. C., Klebanov, P., \&Japel, C. (2007). School readines and later achievement. Development Psychology, 43(6), 1428-144.

[5] Green, E. G. T. (2006). Successful or friendly? Inferring achievement and relational competence from individualist and collectivist attitudes. Swiss Journal of Psychology, 65 (1), $25-36$

[6] Janatin, Mulafi. (2015).The Correlation Between Self Efficacy and Learning Achievement of Grade IV Students at Elementary School Within Group II Bantul Sub District Academic Year 2014/2015. Undergraduate Thesis. Not Published.

[7] Knollmann, M., \& Wild, E. (2007). Quality of parental support and students' emotions during homework: Moderating effects of students'motivational orientations. European Journal of Psychology of Education, 22(1), 63-76.

[8] Latifah, Amalia Nur. (2014). The Effect of Self Efficacy and The School Environment Towards Academic Fraud on Accounting Written Test of Grade XI Students Accounting Expertise Competence Vocational High School Within Kulon Progo Regency Academic Year 2013/2014.

[9] Ottens, A.J. (1991). Coping with Academic Anxiety. New 
York: The RosenPublishing Group.

[10] Sukmadinata, Nana S. (2011). Educational Research Method. Bandung, Indonesia: PT Remaja Rosdakarya.

[11] Yoenanto, N. H. \& Rahadianto, A. I. (2014). The Correlation Between Self Efficacy and Achievement Motivation With Academic Anxiety on Students of RSBI
School Program in Surabaya. Journal of Industrial Psychology and Organization 3 (3), 123-128.

[12] Zimmerman, B. J. (2009). Self-Efficacy and Educational Development. In A.Bandura (Ed.), Self Efficacy in Changing Societies, (pages. 202-231). Cambridge: Cambridge University Press. 